\title{
Hazard Analysis of Cheese Provided for Consumers in Hawassa/Ethiopia
}

Demeke Teklu Senbetu*

Oromia Agricultural Research Institute, Zeway Fishery Resources Research Center, PO Box 229, Ethiopia

\begin{abstract}
The characteristics and the technology of traditional cheese processing are made in general under primitive condition which results in low yield and poor quality of the product. Poor sanitary practices results in public or consumers health hazards due to the presence of pathogenic bacteria mold and yeast. This research activity was initiated with the objective to evaluate the quality of cheese and its hazardousness to consumer's health. In this study a microbial load of 24 samples $\left(S_{1}-S_{24}\right)$ which are collected from the local market and one control group $\left(\mathrm{C}_{\mathrm{G}}\right)$ were determined. The result indicate that aerobic bacterial count for 15 samples left under highest microbiological risk category while only 6 samples shows the moderate risk and the rest left under the acceptable limit. Despite 18 samples which show Staphylococcus Species growth at the highest level of microbiological risk category 6 samples didn't show any growth. 11 samples were shows Salmonella species and Shigella species growth beyond the acceptable limit. Only 9 samples were shows the highest risk through the growth of all total coliform, E-coli and fecal coliform growth whereas the rest shows particular growth. 9 samples for yeast and 4 samples for mold were show highest level of microbiological risk category while 5 samples for yeast and 4 samples for mold were left under moderate risk. 13 samples show the highest microbial load for LAB while 3 samples and the $C_{G}$ left under moderate microbiological risk category. The highest faecal coliform observed from fourteen collected cheese samples could be due to faecal contamination of the processing area and water used for processing. The current result on Staphylococcus Spp. The highest microbial load observed from many of the collected cheese samples could be due to human contact through air particles breathed, coughed or sneezed out during the course of work or from food handlers or from other sources in the air within the processing area. It also could be due to diseased udder, unfavorable storage temperature and/or long period of storage time. Finally, further research work covering wider area and large sample size should be done to identify problems and determine appropriate processing and handling of cheese.
\end{abstract}

Keywords: Cheese; Risk; Microbial Load; Processing; Hazard

\section{Introduction}

Milk is processed on farm using traditional technologies to produce products like butter, ghee, ayib (soft curd type cottage cheese) and sour milk which can be sold. Such techniques have long been used for processing the supply of milk; they seem to provide the only option for conversion of milk in to stable marketable products. The traditional technology for cheese processing and others have remained static owing to the lack of improved production [1,2]. Cheese is a fresh or matured product obtained by draining after coagulation of the whole, skimmed or partially skimmed milk. It is one of the oldest dairy products which are rich in essential amino acid, vitamins, minerals, proteins, calcium and phosphorus.

The characteristics and the technology which are described suggest in developing countries traditional milk product like butter and cheese are made in general under primitive conditions which results in low yield and poor quality of the product. Poor sanitary practices in local cheese processing results in public or consumers health hazard due to the presence of pathogenic bacteria, mold and yeast. Several microorganisms like spoilage and pathogens such as coli-forms, lactobacilli, heat resistant Staphylococcus can grow in cheese or on the surface [3]. Although those human pathogens may not be present in high count, it may indicate a diseased udder, unsanitary handling and/ or unfavorable storage temperature [4]. A high count indicates that there is a greater like-hood of disease transmition.

The proper pasteurization of milk during production of cheese could destroy spoilage organisms and pathogens but a gentle heating called thermization is needed to achieve and stabilize a defined basic quality [5]. Therefore, the bacterial count in locally made cheese is the most reliable indication we have of its sanitary and microbial quality.

Little is known (almost none) about the microbial quality and acceptability of the locally made cheese in Hawassa. It is thus, imperative to assess and determine the microbial quality and safety of the cheese in order to determine its level of hazardousness towards the consumer's health.

\section{Materials and Method}

\section{Study area}

Hawassa town is situated in Sidamo Zone, Southern Nations Nationalities and Peoples of Ethiopia region, Ethiopia $273 \mathrm{Km}$ far from Addis Abeba to the south. The town was divided in to four compartments using imaginary lines and then from each compartments six cheese samples were collected.

\section{Sample collection}

The totals of 24 samples were collected from different local market and dairy shops in Hawassa and 1 control group was prepared aseptically in the laboratory. Samples were packed in pre-sterilized glass jars and cool transported using ice and ice box to Hawassa University Food Science laboratory and Biology laboratory. Microbial load analysis was conducted at Food Science laboratory three times for 12 samples and Biology laboratory three times for 12 samples.

\section{Control group preparation}

Ayib (soft curd type cottage cheese) were prepared in the laboratory

*Corresponding author: Demeke TS, Oromia Agricultural Research Institute Zeway Fishery Resources Research Center, P.O.Box 229, Ethiopia, Te +215464412030; Fax +251464412942; E mail: Demeketeklu@Yahoo.Com

Received October 13, 2013; Accepted December 10, 2013; Published February 10,2014

Citation: Senbetu DT (2014) Hazard Analysis of Cheese Provided for Consumers in Hawassa/Ethiopia. J Food Process Technol 5: 297. doi:10.4172/2157 7110.1000297

Copyright: (C) 2014 Senbetu DT. This is an open-access article distributed under the terms of the Creative Commons Attribution License, which permits unrestricted use, distribution, and reproduction in any medium, provided the original author and source are credited. 
following the same procedure used for Ethiopian traditional cheese processing. The skimmed milk was draining after coagulation.

\section{APC analysis}

Immediately after arrival, 1 gram cheese was added to $9 \mathrm{ml}$ peptone water and homogenized in stomacher bag. Then appropriate serial dilutions $\left(10^{-1}, 10^{-2}, 10^{-3}, 10^{-4}\right.$ and $\left.10^{-5}\right)$ of all samples were prepared and then $0.1 \mathrm{ml}$ of the odd power dilutions were taken and plated using spread plate technique in a duplicate by using a Standard Plate Count Agar (PCA). Finally, it was incubated at $35^{\circ} \mathrm{C}$ for $48 \mathrm{hrs}$ and then number of colony was counted and colony forming units was calculated by multiplying number of colony by its serial dilution factors [5].

\section{Mold and yeast analysis}

$0.1 \mathrm{ml}$ of the odd power dilutions were taken and plated using spread plate technique in a duplicate by using standard Yeast Extract Glucose Chloramphenicol Agar (YGC). Finally, it was incubated at $25^{\circ} \mathrm{C}$ for 5 days then after the result was recorded.

\section{E. coli analysis}

Suspected colonies of the fecal coliform were confirmed in E.C Broth at $44^{\circ} \mathrm{C}$ for 24 hours with the production of gas, after which one loop of the positive tube were transferred into Tryptone water and incubated at $44^{\circ} \mathrm{C}$ for 48 hours 3 drops of Kovac's reagent was added to the test culture and observed for any reaction. Formation of red colour indicated a positive reaction, thereby confirms the presence of Escherichia coli, and recorded those organisms producing red ring as indole positive.

\section{Total coliform analysis}

$0.1 \mathrm{ml}$ of the odd power dilutions will be taken and plated using spread plate technique in a duplicate by using a standard Volatile Red Bile Lactose Agar (VRBLA).Finally, it will be incubated at $30^{\circ} \mathrm{C}$ for 24 hrs then after the result will be recorded [5].

\section{Lab analysis}

$0.1 \mathrm{ml}$ of the odd power dilutions were taken and plated using spread plate technique in a duplicate by using a standard Man Rogssa and Sharp (MRS). Finally, it was incubated at $30^{\circ} \mathrm{c}$ for $48 \mathrm{hrs}$ then after the result was recorded [5].

\section{Staphylococcus Spp analysis}

$1 \mathrm{ml}$ of odd power dilutions was taken and plated using spread plate technique in a duplicate by using a standard Baird-parker agar plates. Finally, it was incubated at $37^{\circ} \mathrm{C}$ for 24 hours and at $37^{\circ} \mathrm{C}$ for 48 hours. Typical colonies of Staphylococcus spp (black or grey, shining and convex), diameter 1.0-1.5 mm after 24 hours incubation and 1.5$2.5 \mathrm{~mm}$ after 48 hours incubation and with each colony surrounded by a clear zone were isolated and tested for coagulase positive as a confirmatory test and finally recorded.

\section{Salmonella spp and Shigella spp analysis}

Immediately after arrival, 25 gram of cheese was added to $225 \mathrm{ml}$ buffered peptone water into an Erlenmeyer flask and Incubate at $36^{\circ} \mathrm{C}$ $\left(+/-1^{\circ} \mathrm{C}\right)$ overnight for 20 hours. On the next day selective enrichment (I) and (II) were prepared and $1 \mathrm{ml}$ of the pre-enrichment broth transferred to $10 \mathrm{ml}$ Tetrathionate broth and Labeled as Tube I. 0.1 $\mathrm{ml}(100 \mathrm{uL})$ of the pre-enrichment broth transfer to $10 \mathrm{ml}$ RappaportVassiliadis soy peptone (RVS) broth and Labeled as Tube II. Then Tube I Incubated at $36.0^{\circ} \mathrm{C} \pm 1{ }^{\circ} \mathrm{C}$ and Tube II Incubated at $41.5^{\circ} \mathrm{C} \pm$ $0.5^{\circ} \mathrm{C}$ overnight for 20 hours. On day three $10 \mu \mathrm{l}$ from the inoculated and incubated Tetrathionate broth (I) and Rappaport-Vassiliadis Soy Peptone (RVS) broth (II) Spread on Xylose lysine desoxycholate (XLD) and on Brilliant Green Agar (BGA) agar plates and incubated at $36.0^{\circ} \mathrm{C} \pm 1{ }^{\circ} \mathrm{C}$ overnight for 24 hours. Day 4: Salmonella Colonies from XLD plates were Selected and Subcultured: A typical Salmonella colony has a slightly transparent red halo and a black centre, a pink-red zone seen in the media surrounding the colonies. Typical Salmonella colonies on a BGA agar plate appear red and impart a red/pink colour to the surrounding agar. Day five to seven: biochemical Identification according to WHO GFN Procedures "Identification of Salmonella and Shigella using an Abbreviated Panel of Tests" [6-10].

\section{Result}

Microbial load analysis was performed on cheese samples which were collected from different market and shops and the following result were obtained (Table 1).

As it is shown on Table 1, the total aerobic bacterial count of 15 samples left under highest microbiological risk category (Table 2) while only 6 samples shows the moderate risk which indicate the potential for development of public health problems and of unacceptable risk, and the rest left under the acceptable limit. 9 samples were show the highest risk through the growth of all total coliform, E-coli and fecal coliform growth whereas 13 samples for E-coli, 14 samples for fecal coliform and 16 samples for total coliform shows the growth beyond the acceptable limits. Despite 18 samples which show Staphylococcus Species growth at the highest level of microbiological risk category 6 samples didn't show any growth. Inspite of the other bacteria's growth Salmonella species and Shigella species didn't show any growth for 13 samples while 7 samples for Shigella species and 6 samples for Salmonella species exceeds the acceptable microbial load for ready to eat foods. For mold count only four samples show highest microbiological risk category through the growth beyond the acceptable limit which could potentially injurious to health and/ or unfit for human consumption while four samples left under moderate risk. Unlike 9 samples which show the highest growth for yeast 10 samples left under the acceptable limit which fits for human consumption while the rest left under moderate microbiological risk category. 13 samples show the highest microbial load for $\mathrm{LAB}$ while 3 samples and the $\mathrm{C}_{\mathrm{G}}$ left under moderate microbiological risk category. As regard lactic acid bacteria 13 cheese samples shows growth that exceeds the acceptable limit whereas 3 samples left under moderate risk. Regarding the control group the microbial load for all parameters conducted in this research left under the acceptable limits for human consumption.

\section{Discussion}

This study explored the quality of cheese provided for the consumers in Hawassa different market and shops. The microorganisms tested were of ready to eat foods safety concern that included Staphylococcus aureus (S. aureus), Escherichia coli (E. coli), lactic acid bacteria(LAB),Aerobic plate count (APC), Salmonella, Shigella, Mould, Yeast, Fecal Coliform, Total Coliform $[10,11]$. The highest aerobic plate count $\left(>10^{5} \mathrm{cfu} / \mathrm{g}\right)$ recorded from 15 samples are due to the existence of predominant microorganism [11].

In a recent study on Monte Veronese cheese, an Italian PDO semihard cheese made with raw milk, Staphylococcus aureus numbers in cheese were higher than the $10^{4} \mathrm{CFU} \mathrm{g}{ }^{-1}$ limit in $78 \%$ of samples [1].

Staphylococcus aureus was the most frequent pathogen associated with cheeses from raw or unspecified milk in food-borne disease 


\begin{tabular}{|c|c|c|c|c|c|c|c|c|c|c|}
\hline No & APC & Mold & Yeast & E.coli & Coliform & Fecal Coliform & LAB & $\begin{array}{c}\text { Staphylococcus } \\
\text { Spp }^{*}\end{array}$ & $\begin{array}{l}\text { Salmonella } \\
\text { Spp }^{*}\end{array}$ & Shigella Spp* \\
\hline $\mathrm{S}_{1}$ & $6.2 \times 10^{4}$ & $<1 \times 10^{1}$ & $7.1 \times 10^{2}$ & $2.0 \times 10^{2}$ & $1.6 \times 10^{3}$ & $1.5 \times 10^{2}$ & $<1 \times 10^{1}$ & $2.3 \times 10^{4}$ & Not isolated & Not isolated \\
\hline$S_{2}$ & $4.8 \times 10^{6}$ & $<1 \times 10^{1}$ & $2.7 \times 10^{4}$ & $<1 \times 10^{1}$ & $4.3 \times 10^{2}$ & $1.1 \times 10^{2}$ & $3.1 \times 10^{5}$ & $<1 \times 10^{1}$ & Isolated & Isolated \\
\hline $\mathrm{S}_{3}$ & $2.2 \times 10^{5}$ & $<1 \times 10^{1}$ & $3.6 \times 10^{5}$ & $<1 \times 10^{1}$ & $<1 \times 10^{1}$ & $<1 \times 10^{1}$ & $5.4 \times 10^{3}$ & $1.4 \times 10^{4}$ & Not isolated & Not isolated \\
\hline $\mathrm{S}_{4}$ & $2.7 \times 10^{5}$ & $2.4 \times 10^{3}$ & $<1 \times 10^{1}$ & $<1 \times 10^{1}$ & $6.4 \times 10^{2}$ & $<1 \times 10^{1}$ & $<1 \times 10^{1}$ & $6.2 \times 10^{5}$ & Isolated & Isolated \\
\hline$S_{5}$ & $2.0 \times 10^{4}$ & $<1 \times 10^{1}$ & $7.1 \times 10^{5}$ & $3.2 \times 10^{2}$ & $1.5 \times 10^{2}$ & $4.7 \times 10^{2}$ & $3.3 \times 10^{4}$ & $<1 \times 10^{1}$ & Not isolated & Not isolated \\
\hline$S_{6}$ & $8.3 \times 10^{7}$ & $6.1 \times 10^{2}$ & $4.1 \times 10^{4}$ & $<1 \times 10^{1}$ & $4.0 \times 10^{2}$ & $<1 \times 10^{1}$ & $<1 \times 10^{1}$ & $4.4 \times 10^{4}$ & Not isolated & Not isolated \\
\hline$S_{7}$ & $5.4 \times 10^{2}$ & $<1 \times 10^{1}$ & $3.1 \times 10^{4}$ & $2.0 \times 10^{2}$ & $<1 \times 10^{1}$ & $<1 \times 10^{1}$ & $<1 \times 10^{1}$ & $6.8 \times 10^{4}$ & Not isolated & Not isolated \\
\hline $\mathrm{S}_{8}$ & $4.4 \times 10^{2}$ & $<1 \times 10^{1}$ & $2.0 \times 10^{3}$ & $<1 \times 10^{1}$ & $1.3 \times 10^{3}$ & $<1 \times 10^{1}$ & $1.6 \times 10^{4}$ & $5.3 \times 10^{5}$ & Isolated & Isolated \\
\hline $\mathbf{S}_{9}$ & $7.3 \times 10^{6}$ & $<1 \times 10^{1}$ & $1.3 \times 10^{4}$ & $4.1 \times 10^{2}$ & $1.2 \times 10^{2}$ & $<1 \times 10^{1}$ & $1.1 \times 10^{4}$ & $7.0 \times 10^{4}$ & Isolated & Isolated \\
\hline $\mathbf{S}_{10}$ & $2.9 \times 10^{4}$ & $1.6 \times 10^{3}$ & $<1 \times 10^{1}$ & $2.5 \times 10^{3}$ & $3.6 \times 10^{2}$ & $1.0 \times 10^{2}$ & $4.7 \times 10^{3}$ & $2.4 \times 10^{5}$ & Not isolated & Not isolated \\
\hline$S_{11}$ & $3.4 \times 10^{7}$ & $<1 \times 10^{1}$ & $<1 \times 10^{1}$ & $1.2 \times 10^{2}$ & $3.1 \times 10^{2}$ & $1.4 \times 10^{2}$ & $3.9 \times 10^{4}$ & $3.6 \times 10^{4}$ & Not isolated & Not isolated \\
\hline$S_{12}$ & $7.5 \times 10^{5}$ & $6.0 \times 10^{4}$ & $<1 \times 10^{1}$ & $8.3 \times 10^{2}$ & $3.6 \times 10^{3}$ & $4.7 \times 10^{2}$ & $3.3 \times 10^{5}$ & $6.2 \times 10^{4}$ & Not isolated & Not isolated \\
\hline$S_{13}$ & $4.7 \times 10^{4}$ & $<1 \times 10^{1}$ & $<1 \times 10^{1}$ & $1.1 \times 10^{3}$ & $1.3 \times 10^{2}$ & $4.0 \times 10^{3}$ & $<1 \times 10^{1}$ & $5.3 \times 10^{5}$ & Not isolated & Not isolated \\
\hline$S_{14}$ & $4.1 \times 10^{6}$ & $<1 \times 10^{1}$ & $7.0 \times 10^{2}$ & $<1 \times 10^{1}$ & $<1 \times 10^{1}$ & $1.0 \times 10^{2}$ & $<1 \times 10^{1}$ & $8.6 \times 10^{4}$ & Isolated & Isolated \\
\hline$S_{15}$ & $3.9 \times 10^{6}$ & $<1 \times 10^{1}$ & $<1 \times 10^{1}$ & $<1 \times 10^{1}$ & $<1 \times 10^{1}$ & $<1 \times 10^{1}$ & $<1 \times 10^{1}$ & $4.2 \times 10^{5}$ & Not isolated & Not isolated \\
\hline$S_{16}$ & $5.7 \times 10^{4}$ & $2.1 \times 10^{2}$ & $5.4 \times 10^{3}$ & $6.1 \times 10^{3}$ & $4.1 \times 10^{2}$ & $8.5 \times 10^{2}$ & $6.1 \times 10^{3}$ & $<1 \times 10^{1}$ & Isolated & Isolated \\
\hline$S_{17}$ & $6.1 \times 10^{5}$ & $<1 \times 10^{1}$ & $1.8 \times 10^{4}$ & $2.2 \times 10^{2}$ & $<1 \times 10^{1}$ & $4.1 \times 10^{2}$ & $<1 \times 10^{1}$ & $9.2 \times 10^{4}$ & Isolated & Isolated \\
\hline $\mathrm{S}_{18}$ & $4.2 \times 10^{2}$ & $1.0 \times 10^{2}$ & $3.6 \times 10^{3}$ & $<1 \times 10^{1}$ & $1.4 \times 10^{2}$ & $<1 \times 10^{1}$ & $1.8 \times 10^{3}$ & $<1 \times 10^{1}$ & Not isolated & Not isolated \\
\hline$S_{19}$ & $2.4 \times 10^{3}$ & $2.4 \times 10^{2}$ & $<1 \times 10^{1}$ & $5.3 \times 10^{2}$ & $4.7 \times 10^{3}$ & $1.0 \times 10^{2}$ & $7.8 \times 10^{2}$ & $3.1 \times 10^{5}$ & Not isolated & Not isolated \\
\hline$S_{20}$ & $5.3 \times 10^{6}$ & $<1 \times 10^{1}$ & $6.2 \times 10^{4}$ & $3.0 \times 10^{2}$ & $<1 \times 10^{1}$ & $<1 \times 10^{1}$ & $1.6 \times 10^{3}$ & $<1 \times 10^{1}$ & Isolated & Isolated \\
\hline$S_{21}$ & $9.0 \times 10^{5}$ & $<1 \times 10^{1}$ & $1.1 \times 10^{4}$ & $<1 \times 10^{1}$ & $<1 \times 10^{1}$ & $<1 \times 10^{1}$ & $6.1 \times 10^{4}$ & $1.8 \times 10^{4}$ & Isolated & Isolated \\
\hline$S_{22}$ & $6.7 \times 10^{5}$ & $<1 \times 10^{1}$ & $<1 \times 10^{1}$ & $6.0 \times 10^{2}$ & $7.4 \times 10^{2}$ & $2.5 \times 10^{3}$ & $6.1 \times 10^{2}$ & $<1 \times 10^{1}$ & Not isolated & Not isolated \\
\hline $\mathrm{S}_{23}$ & $3.4 \times 10^{6}$ & $<1 \times 10^{1}$ & $<1 \times 10^{1}$ & $<1 \times 10^{1}$ & $<1 \times 10^{1}$ & $2.0 \times 10^{2}$ & $5.7 \times 10^{2}$ & $5.4 \times 10^{4}$ & Isolated & Isolated \\
\hline$S_{24}$ & $1.9 \times 10^{6}$ & $1.9 \times 10^{3}$ & $<1 \times 10^{1}$ & $<1 \times 10^{1}$ & $1.5 \times 10^{2}$ & $1.0 \times 10^{3}$ & $6.1 \times 10^{4}$ & $2.1 \times 10^{5}$ & Isolated & Isolated \\
\hline$C_{G}$ & $7.3 \times 10^{4}$ & $<1 \times 10^{1}$ & $<1 \times 10^{1}$ & $<1 \times 10^{1}$ & $<1 \times 10^{1}$ & $1.5 \times 10^{2}$ & $3.8 \times 10^{2}$ & $5.1 \times 10^{3}$ & Isolated & Isolated \\
\hline
\end{tabular}

Table 1: Average CFU/gram of twenty four cheese samples.

outbreaks reported in France in 1992-1997 [12]. None of these studies could clearly demonstrate the origin of contamination which could derive from raw milk since Staphylococcus aureus is the commonest cause of mastitis in dairy animals but also from post-processing contamination through unhygienic handling of products [13].

Enterobacteriaceae are ubiquitous inhabitants of the gut of human beings and other warm-blooded animals. Members of this group include the generally harmless and commensal E. coli which owing to its occurrence in feces, ready culturability, and typically nonpathogenic character, has been adopted as a universal indicator of fecal contamination. The high viable counts of The Enterobacteriaceae, (Salmonella, Shigella, E. coli) exhibited by many of the cheeses I sampled may be ascribed to the use of raw milk and linked to poor husbandry of producing animals, poor hygiene practices during milk collection or bad preservation, possibly connected with lack of milk cooling. Otherwise, post-thermal treatment contamination must be hypothesized with organisms originally derived from raw milk or from manufacturing environments [14].

The presence of human enteric organisms on many cheese products is clear evidence of contamination from a terrigenous source [15]. The highest feacal coliform observed from fourteen collected cheese samples could be due to feacal contamination of the processing area and water used for processing (this contamination has normally been associated with pollution of natural waters or water environments) or through direct contamination of products during processing.

The appearance of mould on four cheese samples and yeast on ten cheese samples can explained as yeast and moulds are widely distributed in the environment and can enter food through inadequately sanitized equipment or as air borne contaminants. The reason for highest yeast and mould counts in present study is due to long period of storage and / or storage at high temperature of the product [16].
The highest growth for Salmonella species on six samples and Shigella species on seven samples could be attributed to lack of temperature during processing of the product as recent study shows that no growth for soft cheese product treated with thermization [17].

This study discovered the presence of the non-lactic and lactic acid bacteria, the non-lactic isolates present in the cheese samples may develop during the milking process, milk collection and cheese making process while the lactic isolates are indigenous to raw milk which is the predominant micro flora found in milk, cheese and milk products $[18,19]$. Therefore, the highest lactic acid bacteria found on thirteen cheese samples could be its indigenousness to the raw milk.

\section{Conclusion and Recommendation}

Cheese of good quality should have counts of total bacteria of less than 10 per gram faecal coliforms and total coliforms should not exceed 100/gm. Total coliform count of sixteen samples, the faecal coliform count of fourteen samples and $E$. coli count of thirteen samples in this study exceeded the acceptable limit recommended. This indicates human health risk due to consumption of those cheese products. Therefore, precautions should be taken to prevent contamination during post-harvest handling and processing of cheese.

Cheese can be considered a good medium for bacterial growth due to their nutrient content and long storage duration. Several steps in their production can cause bacteriological hazards. Though pasteurization of milk can destroy most of the pathogens posing risk to public health, yet, the potential bacteriological hazards can still be found in the final products after pasteurization through the addition of contaminated ingredients or improper handling. The results indicate the unhygienic conditions prevailing during distribution or sale where most of the products are sold in open containers and market. 
Citation: Senbetu DT (2014) Hazard Analysis of Cheese Provided for Consumers in Hawassa/Ethiopia. J Food Process Technol 5: 297. doi:10.4172/2157-7110.1000297

Page 4 of 5

\begin{tabular}{|c|c|c|c|c|c|}
\hline Hazard & Result & $\begin{array}{l}\text { Microbiological } \\
\text { Risk Category }\end{array}$ & Interpretation & Likely Cause & $\begin{array}{l}\text { Suggested Actions (Not exclusive) } \\
\text { NB: Perform risk assessment before } \\
\text { any further action }\end{array}$ \\
\hline $\begin{array}{l}\text { Escherichia coli } \\
\text { O157 } \\
\text { (and other } \\
\text { Verocyto toxin } \\
\text { producing } \\
\text { coliforms (VTEC)) }\end{array}$ & $\begin{array}{l}\text { Detected } \\
\text { Not detected }\end{array}$ & $\begin{array}{l}\text { High } \\
\text { Low }\end{array}$ & $\begin{array}{l}\text { Unsatisfactory: } \\
\text { Potentially injurious } \\
\text { to health and/ or unfit } \\
\text { for human consumption } \\
\text { Satisfactory }\end{array}$ & $\begin{array}{l}\text { Inadequate processing } \\
\text { Cross contamination }\end{array}$ & $\begin{array}{l}\text { Immediate investigation of: the food origin, production } \\
\text { process and environment; take investigative food samples } \\
\text { and consider environmental monitoring. } \\
\text { N/A }\end{array}$ \\
\hline Salmonella spp. & $\begin{array}{l}\text { Detected } \\
\text { Not detected }\end{array}$ & $\begin{array}{l}\text { High } \\
\text { Low }\end{array}$ & $\begin{array}{l}\text { Unsatisfactory: } \\
\text { Potentially injurious } \\
\text { to health and/ or unfit } \\
\text { for human consumption } \\
\text { Satisfactory }\end{array}$ & $\begin{array}{l}\text { Inadequate processing Cross } \\
\text { contaminating }\end{array}$ & $\begin{array}{l}\text { Immediate investigation of: the food origin, production } \\
\text { process and environment; take investigative food samples } \\
\text { and consider environmental monitoring. } \\
\text { N/A }\end{array}$ \\
\hline Shigella spp. & $\begin{array}{l}\text { Detected } \\
\text { Not detected }\end{array}$ & $\begin{array}{l}\text { High } \\
\text { Low }\end{array}$ & $\begin{array}{l}\text { Unsatisfactory: } \\
\text { Potentially injurious } \\
\text { to health and/ or unfit } \\
\text { for human consumption } \\
\text { Satisfactory }\end{array}$ & $\begin{array}{l}\text { Cross contamination by } \\
\text { food handler or fecal } \\
\text { contamination of raw product }\end{array}$ & $\begin{array}{l}\text { Immediate investigation of hygiene, } \\
\text { Cleaning and food handlers in outbreaks. } \\
\text { N/A }\end{array}$ \\
\hline Yeast & $\begin{array}{l}10^{2}-10^{4} \\
<10^{2}\end{array}$ & $\begin{array}{l}\text { Moderate } \\
\text { Low }\end{array}$ & $\begin{array}{l}\text { Unsatisfactory: } \\
\text { Potentially injurious to } \\
\text { health and/ or unfit for } \\
\text { human consumption } \\
\text { Borderline } \\
\text { Satisfactory }\end{array}$ & $\begin{array}{l}\text { Strong evidence for poor } \\
\text { handling and temperature } \\
\text { control or long storage } \\
\text { period. } \\
\text { Likely evidence for poor } \\
\text { handling, process and } \\
\text { temperature control and long } \\
\text { storage period. }\end{array}$ & $\begin{array}{l}\text { Immediately review food handling as well as temperature } \\
\text { and time controls. Take investigative samples of food, food } \\
\text { preparation environment and food handlers. } \\
\text { Risk will increase proportional to the } \\
\text { levels detected and the likelihood of } \\
\text { subsequent growth in the absence of } \\
\text { appropriate levels of control. Review handling as well as } \\
\text { processing controls.Consider taking investigative samples } \\
\text { of food, food preparation environment and food handlers. } \\
\text { N/A }\end{array}$ \\
\hline $\begin{array}{l}\text { Staphylococcus } \\
\text { Spp* }\end{array}$ & $\begin{array}{l}>10^{4} \\
20^{2}-10^{4} \\
<20\end{array}$ & $\begin{array}{l}\text { High } \\
\text { Moderate } \\
\text { Low }\end{array}$ & $\begin{array}{l}\text { Unsatisfactory: } \\
\text { Potentially injurious to } \\
\text { health and/ or unfit for } \\
\text { human consumption } \\
\text { Borderline } \\
\text { Satisfactory }\end{array}$ & $\begin{array}{l}\text { Strong evidence for poor } \\
\text { handling and temperature } \\
\text { control. } \\
\text { Likely evidence for poor } \\
\text { handling, process and } \\
\text { temperature control. }\end{array}$ & $\begin{array}{l}\text { Immediately review food handling as well as temperature } \\
\text { and time controls. Take investigative samples of food, food } \\
\text { preparation environment and food handlers. } \\
\text { Risk will increase proportional to the } \\
\text { levels detected and the likelihood of } \\
\text { subsequent growth in the absence of } \\
\text { appropriate levels of control. Review } \\
\text { handling as well as processing controls, especially if there } \\
\text { opportunities for growth of staphylococci during processing } \\
\text { or maturation of the product. } \\
\text { Consider taking investigative samples of food, food } \\
\text { preparation environment and food handlers. } \\
\text { N/A }\end{array}$ \\
\hline APC & $\begin{array}{l}>10^{5} \\
10^{3}-10^{5} \\
<10^{3}\end{array}$ & $\begin{array}{l}\text { High } \\
\text { Moderate } \\
\text { Low }\end{array}$ & $\begin{array}{l}\text { Unsatisfactory: } \\
\text { Potentially injurious to } \\
\text { health and/ or unfit for } \\
\text { human consumption } \\
\text { Borderline } \\
\text { Satisfactory }\end{array}$ & $\begin{array}{l}\text { Strong evidence for poor } \\
\text { handling and temperature } \\
\text { control } \\
\text { Likely evidence for poor } \\
\text { handling, process and } \\
\text { temperature control. }\end{array}$ & $\begin{array}{l}\text { Immediate investigation of hygiene, cleaning and food } \\
\text { handlers in outbreaks. } \\
\text { Risk will increase proportional to the levels detected and } \\
\text { the likelihood of subsequent growth in the absence of } \\
\text { appropriate levels of control. Review handling as well as } \\
\text { processing controls, especially if there opportunities for } \\
\text { growth of staphylococci during processing or maturation of } \\
\text { the product. Consider taking investigative samples of food, } \\
\text { food preparation environment and food handlers. } \\
\text { N/A }\end{array}$ \\
\hline Mould & $\begin{array}{l}>10^{3} \\
10^{2}-10^{3} \\
<10^{2}\end{array}$ & $\begin{array}{l}\text { High } \\
\text { Moderate } \\
\text { Low }\end{array}$ & $\begin{array}{l}\text { Unsatisfactory: } \\
\text { Potentially injurious to } \\
\text { health and/ or unfit for } \\
\text { human consumption } \\
\text { Borderline } \\
\text { Satisfactory }\end{array}$ & $\begin{array}{l}\text { Strong evidence for poor } \\
\text { handling and } \\
\text { Temperature control or long } \\
\text { storage period. } \\
\text { Likely evidence for poor } \\
\text { handling, process and } \\
\text { temperature control and long } \\
\text { storage period. }\end{array}$ & $\begin{array}{l}\text { Immediately review food handling as well as temperature } \\
\text { and time controls. Take investigative samples of food, food } \\
\text { preparation environment and food handlers. } \\
\text { Risk will increase proportional to the levels detected and } \\
\text { the likelihood of subsequent growth in the absence of } \\
\text { appropriate levels of control. Review handling as well as } \\
\text { processing controls. Consider taking investigative samples } \\
\text { of food, food preparation environment and food handlers. } \\
\text { N/A }\end{array}$ \\
\hline $\begin{array}{l}\text { Lactic Acid } \\
\text { Bacteria }\end{array}$ & $\begin{array}{l}>10^{3} \\
10^{2}-10^{3} \\
<10^{2}\end{array}$ & $\begin{array}{l}\text { High } \\
\text { Moderate } \\
\text { Low }\end{array}$ & $\begin{array}{l}\text { Unsatisfactory: } \\
\text { Potentially injurious to } \\
\text { health and/ or unfit for } \\
\text { human consumption } \\
\text { Borderline } \\
\text { Satisfactory }\end{array}$ & $\begin{array}{l}\text { Strong evidence for poor } \\
\text { processing and temperature } \\
\text { control } \\
\text { Likely evidence for poor } \\
\text { processing and temperature } \\
\text { control }\end{array}$ & $\begin{array}{l}\text { Immediately review food handling as well as temperature } \\
\text { and time controls. Take investigative samples of food, } \\
\text { food preparation environment and food handlers. Risk } \\
\text { will increase proportional to the levels detected and } \\
\text { the likelihood of subsequent growth in the absence of } \\
\text { appropriate levels of control. Review handling as well as } \\
\text { processing controls. Consider taking investigative samples } \\
\text { of food, food preparation environment and food handlers. } \\
\text { N/A }\end{array}$ \\
\hline
\end{tabular}

Borderline-Test results that are not unsatisfactory but are also not satisfactory, are on the upper limit of acceptability and which indicate the potential for development of public health problems and of unacceptable risk.

Foodborne outbreak -An incidence, observed under given circumstances, of two or more human cases of the same disease and/or infection, or a situation in which the observed number of cases exceeds the expected number and where the cases are linked, or are probably linked, to the same food source (Directive 2003/99/EC60). Risk -A function of the probability of an adverse health effect and the severity of that effect, consequential to a hazard (Regulation (EC) No. 178/2002).

Table 2: Microbiological Limits for Assessment of Microbiological Quality. 
Citation: Senbetu DT (2014) Hazard Analysis of Cheese Provided for Consumers in Hawassa/Ethiopia. J Food Process Technol 5: 297. doi:10.4172/2157-7110.1000297

Page 5 of 5

It is recommended to use and implement immediate regulatory measures like good processing practices as well as distribution and retail storage practices for ensuring microbiological safety of cheese provided for Hawassa. Finally, further research work covering wider area and large sample size should be done to identify problems and determine appropriate processing and set standards for production of cheese. The need of training and capacity building program for cheese processors and cheese vending communities has been suggested.

\section{Acknowledgement}

The author is grateful to God.

\section{References}

1. Poli A, Guglielmini E, Sembeni S, Spiazzi M, Dellaglio F, et al. (2007) Detection of Staphylococcus aureus and enterotoxin genotype diversity in Monte Veronese, a Protected Designation of Origin Italian cheese. Lett Appl Microbiol 45: 529-534

2. Eyasu B (1989) Technology of traditional milk products of the People Democratic Republic of Ethiopia and Republic of Mali. FAO manuscript.

3. Zottola EA, Smith LB (1997) Growth and survival of undesirable bacteria in dairy products.

4. Baron, Samuel (2001) Medical microbiology (4th Edition).Va.ASM press, USA.

5. Richardson GH (1985) Standard method for analysis of dairy products (15 Edition). American Public Health Association, Washington DC, USA

6. The Nordic Committee on Food Analysis: General guidelines on Salmonella, Shigella, Staphylococci and E. coli spp. bacteria determination in foods. Review paper, Norwegian National Committee, Oslo, Norway.

7. The Nordic Committee on Food Analysis: General guidelines on Aerobic microorganisms and coliform spp. bacteria determination in foods. Review paper, Norwegian National Committee, Oslo, Norway.
8. Diliello LR (1998) Methods in food and dairy microbiology. State university of New York. AVI press, NY, USA

9. WHO Global Foodborne Infections Network (2010) Laboratory Protocol: "Isolation of Salmonella spp. From Food and Animal Faeces" ( $5^{\text {th }}$ Edition.).

10. WHO Global Foodborne Infections Network (2010) Laboratory Protocol: "Biochemical Identification of Salmonella and Shigella Using an Abbreviated Panel of Tests" (3rd Edition).

11. Health Protection Agency (2009) Guidelines for Assessing the Microbiological Safety of Ready-to-Eat Foods. London. Health Protection Agency.

12. De Buyser ML, Dufour B, Maire M, Lafarge $V$ (2001) Implication of milk and milk products in food-borne diseases in France and in different industrialized countries. Int J Food Microbiol 67: 1-17.

13. Little CL, De Louvois J (1999) Health risks associated with unpasteurized goats and ewes' milk on retail sale in England and Wales. A PHLS Dairy Products Working Group Study. Epidemiol Infect 122: 403-408.

14. Giammanco GM, Pepe A, Aleo A, D’Agostino V, Milone S, et al. (2011) Microbiological quality of Pecorino Siciliano "primosale" cheese on retail sale in the street markets of Palermo, Italy. New Microbiol 34: 179-185.

15. ICMSF (1986) Microorganisms in Foods 2. Sampling for microbiological analysis: Principles and specific applications. Blackwell Scientific Publications.

16. IOM (1985) An evaluation of the role of microbiological criteria for foods and food ingredients.

17. Varga L (2007) Microbiological quality of commercial dairy products. Communicating Current Research and Educational Topics and Trends in Applied Microbiology.

18. Neviani E, Mucchetti G, Contarini G, Carini S (1982) Enterococc neiformaggiitaliani. Loropresenza in formaggi di monte e impiego in uninnestoselzionato. $7:$ 72-78.

19. Jones CK (1959) Application and limitation of quality test for milk and milk products: A review. J Dairy Sci 42: 8-18. 